\title{
Chronic Oral Administration of Beta-Adrenoceptor Agonist Clenbuterol Affects Myosin Heavy Chain (MHC) Expression in Adult Mouse Heart
}

\author{
S. N. PATIYAL, S. SHARMA \\ Department of Biosciences, Himachal Pradesh University Summer Hill, Shimla, India
}

Received February 8, 2006

Accepted May 5, 2006

On-line available June 22, 2006

\begin{abstract}
Summary
The aim of this study was to analyze the effects of chronic administration of the $\beta$-adrenoceptor agonist clenbuterol ( $2 \mathrm{mg} / \mathrm{kg}$ body weight/day for a period of 30 days) on the major contractile protein (myosin) in the left ventricular muscle of the adult mouse heart. Separation of myosin heavy chain (MHC) isoforms on $7.5 \%$ glycerol SDS-PAGE and subsequent quantification of the gels by laser densitometry showed a 6.5 -fold increase in the $\beta$-isoform of MHC in the clenbuterol-treated group. The $\alpha$ : $\beta$ ratio of these two isoforms in the control group was $98.16 \pm 0.14 \%: 1.83 \pm 0.14 \%$, whereas in the treated group it was $88.05 \pm 1.15 \%: 11.95 \pm 1.15 \%$. Actomyosin ATPase activity assay demonstrated a significant $(20 \%)$ decline in ATPase activity of the tissue in the $\beta$-agonist-treated group. These results suggest that chronic clenbuterol treatment is capable to induced the transformation of MHC isoforms increasing the slow $\beta$-MHC isoform, which may contribute to the altered contractile mechanics of clenbuterol-treated hearts.
\end{abstract}

Key words

Clenbuterol $\bullet$ Myosin heavy chain isoforms $\bullet$ Left ventricle $\bullet$ Actomyosin ATPase $\bullet$ Cardiac muscle contraction

\section{Introduction}

Myosin is the molecular motor of the heart that generates force and motion by coupling its ATPase activity to its cyclic interaction with actin. Myosin is a hexameric protein, which is composed of two heavy chains, two essential and two regulatory light chains. In the mammalian heart, two functionally different MHC isoforms namely MHC- $\alpha$ and MHC- $\beta$ are present. The functional difference between the two MHC isoforms in terms of shortening velocity, force generation and ATPase activity are profound (Litten et al. 1982, Palmitter et al. 1999) and the differential expression of the two isoforms changes under pathological conditions. There is a shift from $\beta$-MHC predominance around birth to $\alpha$-MHC predominance in the ventricles of the heart and adult mouse heart contains only $\alpha$-isoform of myosin heavy chain. However, in larger animals and in humans $\beta$-MHC remains as the major isoform. Numerous stimuli can shift the MHC composition of the mammalian heart including developmental stage, thyroid status, exercise conditioning and hemodynamic load. Thyroid hormones, that are a potent inducers of faster contracting $\alpha-\mathrm{MHC}$ isoform, dramatically affect the MHC composition. On the contrary, hypothyroidism, pressure overload and heart failure significantly decrease $\alpha-\mathrm{MHC}$ and enhance the $\beta$ - 
MHC expression in mammals (Nadal-Gonard and Madhvi 1997).

Primary amino acid sequences of the two MHC are $93 \%$ identical, despite their functional diversity. The contractile velocity and ATP consumption of the heart have been shown to correlate with the relative proportion of each isoform, with $\alpha$-MHC possessing two to three times higher ATPase activity and contraction speed (Pope et al. 1980, Vanburen et al. 1995). However, $\beta-\mathrm{MHC}$ produces two times higher cross-bridge force with higher economy of energy consumption (Harris et al. 1994). Hence, the relative proportion of the two isoforms is critical in determining the contractile performance of the heart.

Protein anabolic effects of $\beta$-adrenoceptor agonists such as clenbuterol, isoproterenol and cimaterol are widely known (Choo et al. 1992, Kim and Sainz 1992, Kumar et al. 2003). Among these, clenbuterol has a considerable therapeutic potential by reversing conditions such as denervation atrophy (Zeman et al. 1987, Agrawal et al. 2003) and muscular dystrophy (Rothwell and Stock 1985). Clenbuterol is also an efficient bronchodilator, which has been used in relieving respiratory disorders in animals and humans (Boyd et al. 1994). This compound is widely used for the treatment of asthma, in relation to its relaxant action on smooth muscle, and to promote muscle growth in humans and in farm animals. Clenbuterol can induce hypertrophy of striated muscles and may also lead to the development of a faster contracting muscle phenotype (Petrou et al. 1999). Clenbuterol is also used as an adjunct to ventricular assist devices (Hon and Yacoub 2003). But chronic clenbuterol treatment has been reported to cause cardiac hypertrophy and collagen infiltration in the wall of the left ventricle in rat and mouse models (Duncan et al. 2000, Patiyal and Katoch 2006). Chronic clenbuterol treatment has also been shown to decrease the exercise performance (Ingall et al. 1996, Duncan et al. 2000). Competitive and recreational athletes and body builders have long abused clenbuterol in their search for enhanced performance (Delbecke et al. 1995), but recent studies have also shown that such treatment can cause reparative fibrosis resulting in accumulation of collagen (Patiyal and Katoch 2005, 2006). Other recent studies (Burniston et al. 2002, 2005) have shown that even a single dose of clenbuterol initiates apoptosis (1 $\mu \mathrm{g} / \mathrm{mg}$ body weight) and myonecrosis (100 $\mu \mathrm{g} / \mathrm{mg}$ body weight) in heart ventricle, hence resulting in a pathophysiological state. Myosin, which is the most abundant contractile protein, is a primary consumer of ATP during contractile activity and isoform switch can result in important functional changes in the muscle, e.g. contractile mechanics and energy utilization. There are no reports in which the expression of myosin has been studied during $\beta$-agonist therapy. Therefore, the present study was aimed to investigate the effects of chronic clenbuterol treatment (at a dose at which most protein anabolic effects of the drug have been studied) on MHC isoform levels and the ATPase activity in the left ventricle of mice heart.

\section{Methods}

Animals

All procedures including the maintenance of animals had an approval of Institutional Animals Ethics Committee of the university. Eight-week old Swiss albino male mice weighing between 22-26 g were purchased from Central Research Institute Kasauli (H.P.) India and maintained in the animal house of the department of Biosciences of Himachal Pradesh University under suitable hygienic conditions providing daylight of $16 \mathrm{~h}$ and temperature $24 \pm 2{ }^{\circ} \mathrm{C}$. These mice were provided feed and water ad libitum.

\section{Drug dosage and sampling time}

A dose of $2 \mathrm{mg} / \mathrm{kg}$ body weight was selected as the protein anabolic effect of the drug had been mostly studied at this dose rate. The 30 -day period was selected as it has been reported to cause significant cardiac hypertrophy (Patiyal and Katoch 2006).

\section{Route of drug administration}

Mice were divided into control and experimental groups. Animals of the latter group were administered a daily dose of clenbuterol ( $2 \mathrm{mg} / \mathrm{kg}$ body weight in physiological saline) orally (gavage method) for 30 days. Control animals received an equal volume of the vehicle (physiological saline). A stock solution of clenbuterol (10 $\mathrm{mg} / \mathrm{ml}$ ) was prepared and further dilutions were made at the time of drug administration. Since clenbuterol is readily oxidized in the presence of light, care was taken to protect the drug from light. Mice were killed $24 \mathrm{~h}$ after the last dose of the drug was administered, i.e. after 30 days. Hearts were dissected out, cleared of adventitia and fat. Ventricles were excised and washed extensively in saline. Only left ventricular (LV) tissue was processed for further experiments. 


\section{Myofibrillar protein extraction}

Myofibrillar proteins were prepared by using the method of Tsika et al. (1987). All homogenates and suspensions were maintained on ice and all buffers were kept at $4{ }^{\circ} \mathrm{C}$. Briefly, each muscle sample from the left ventricle was homogenized in $10 \mathrm{vol}$ of a solution containing (in mM) 250 sucrose, $100 \mathrm{KCl}, 20$ imidazole, and 5 EDTA (pH 6.8). The homogenate was centrifuged at $1000 \mathrm{xg}$ for $15 \mathrm{~min}$. The supernatant fraction was discarded and the pellet was rehomogenized in $10 \mathrm{vol}$ of $175 \mathrm{mM} \mathrm{KCl}$ containing $0.5 \%$ Triton X-100 (pH; 6.8) and processed through two additional washings. The myofibrillar pellet was again rehomogenized in $10 \mathrm{vol}$ of $150 \mathrm{mM} \mathrm{KCl}$ and $20 \mathrm{mM}$ imidazole $(\mathrm{pH} \mathrm{7.0)}$ and centrifuged at $1000 \mathrm{xg}$ for $10 \mathrm{~min}$, the supernatant fraction was discarded and the resulting pellet was resuspended in the same buffer. Total protein concentration was determined by the method of Lowry et al. (1951).

\section{Extraction of native myosin}

All preparations were carried out on ice. Ventricular muscle tissue was homogenized in a phosphate buffer (x10 vol) comprising $10 \mathrm{mM}$ sodium phosphate, $1 \mathrm{mM}$ EGTA, and $1 \mathrm{mM}$ PMSF and centrifuged at $10000 \mathrm{xg}, 4{ }^{\circ} \mathrm{C}$. The supernatant was discarded and the pellet was resuspended in a GubaStraub extraction buffer $\left(300 \mathrm{mM} \mathrm{NaCl}, 1 \mathrm{mM} \mathrm{MgCl}{ }_{2}\right.$, $10 \mathrm{mM} \quad \mathrm{Na}_{4} \mathrm{P}_{2} \mathrm{O}_{7}, \quad 10 \quad \mathrm{mM} \quad$ EDTA, $0.1 \%$ 2-mercaptoethanol, and $5 \mu \mathrm{g} / \mathrm{ml}$ leupeptin) and maintained at $\mathrm{pH} 8.8$. Following $2 \mathrm{~h}$ of continuous stirring, the extract was centrifuged $(10000 \mathrm{xg}$ for $15 \mathrm{~min})$ at $4{ }^{\circ} \mathrm{C}$. Supernatant containing myosin was mixed with glycerol $(1: 1)$ and stored at $-20{ }^{\circ} \mathrm{C}$ for subsequent analysis. Purity of native myosin was checked by carrying out pyrophosphate polyacrylamide gel electrophoresis (PPi-PAGE) as performed by Hoh et al. (1976), already described elsewhere (Ramesh et al. 1997).

\section{SDS-PAGE (myofibrillar proteins)}

Myofibrillar proteins were analyzed by involving denaturing conditions as described by Laemmli (1970). A $12 \mu \mathrm{l}$ aliquot was removed from the myofibrillar protein sample, diluted with $48 \mu$ of SDS sample buffer, and heated to $100{ }^{\circ} \mathrm{C}$ for $4 \mathrm{~min}$. Electrophoresis was carried out on $12.5 \%$ separating and $4.5 \%$ stacking gel. Electrophoresis was run at constant current of $15 \mathrm{~mA}$ per slab in stacking gel and $20 \mathrm{~mA}$ per slab in separating gel. Gels were stained with coommasie brilliant blue (CBB). Different myofibrillar proteins were identified by running suitable markers (Sigma). The separated proteins were quantified in an Alpha infotech Ultrascan densitometer. To normalize the data for densitometry, equal amount of proteins were always loaded.

\section{Separation and analysis of myosin heavy chain (MHC)}

In separate experiments native myosin extracted in Guba Straub solution, as well as myofibrillar protein extract both were processed for MHC analysis. Samples were mixed with Laemmli's sample buffer and boiled for $2 \mathrm{~min}$ before these were applied on SDS-PAGE. Electrophoresis was carried out under the conditions as described by Piao et al. (2003). Briefly, the separating gel consisted of glycerol $(5 \%, \mathrm{v} / \mathrm{v})$, acrylamide $(7 \%, \mathrm{w} / \mathrm{v})$, Tris $(3 \mathrm{M})$, glycine $(1 \mathrm{M})$, and SDS $(10 \%$, w/v). Stacking gel consisted of glycerol $(5 \%, \mathrm{v} / \mathrm{v})$, acryl amide $(4 \%$, $\mathrm{w} / \mathrm{v})$, Tris $(0.5 \mathrm{M})$, glycine $(0.16 \mathrm{M})$, EDTA $(0.1 \mathrm{M})$ and SDS $(10 \%, \mathrm{w} / \mathrm{v})$. The electrophoresis was carried out in a running buffer comprising of Tris base $(0.1 \mathrm{M})$, glycine $(0.16 \mathrm{M}), \operatorname{SDS}(1 \%, \mathrm{w} / \mathrm{v})$ at a constant voltage of $140 \mathrm{~V}$ for $8 \mathrm{~h}$ in cold environment $\left(4{ }^{\circ} \mathrm{C}\right)$. Gels were stained with CBB. To further confirm the results of these experiments myosin isoforms separated on native gels were excised, equilibrated in Laemmli's buffer for $30 \mathrm{~min}$ at $37{ }^{\circ} \mathrm{C}$ and immediately processed on glycerol SDSPAGE for MHC isoform expression. The relative proportions of the separated isoforms were quantified in an Alpha Infotech ultra scan gel densitometer. Each optical density obtained was then expressed as percentage of total MHC content for the corresponding gel.

\section{Actomyosin ATPase activity assay}

LV tissue was homogenized in 10 vol of a solution containing $\mathrm{KCl}(50 \mathrm{mM}), \mathrm{MgCl}_{2}(7 \mathrm{mM})$, Tris $(20 \mathrm{mM})$, and $0.5 \%$ Triton-X 100. The extract was immediately centrifuged at $8000 \mathrm{xg}$ for $20 \mathrm{~min}$ at $4{ }^{\circ} \mathrm{C}$. The supernatant was discarded and the pellet was mixed and dissolved in high ionic strength solution containing $\mathrm{KCl}(0.4 \mathrm{M})$, Tris $(20 \mathrm{mM}, \mathrm{pH} 7.0), \mathrm{NaHCO}_{3}(1 \mathrm{mM})$ and $\mathrm{NaN}_{3}(0.1 \mathrm{mM})$. The homogenate was again centrifuged at $8000 \mathrm{xg}$ for $20 \mathrm{~min}$ to obtain the supernatant containing actomyosin. The purity of the actomyosin complex was established by running it on $10 \%$ SDSPAGE. The proteins contents of the crude actomyosin complex were calculated according to Lowry et al. (1951). 


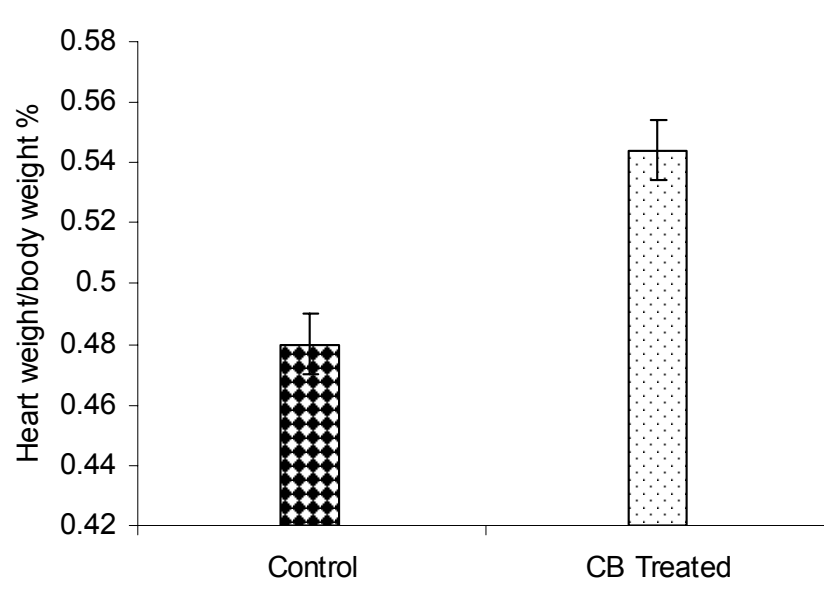

Fig. 1. Effect of clenbuterol $(\mathrm{CB})$ on heart weight/body weight ratio. * significant increase $(n=15, p<0.05)$ in relative heart weight indicated the onset of significant cardiac hypertrophy in the CB-treated group. Values are mean \pm SEM.

Enzymatic activity of the myofibrils was assayed at $27{ }^{\circ} \mathrm{C}$ in a medium that comprised $\mathrm{KCl}$ (50 mM), Tris (20 mM; pH 7.0), $\mathrm{CaCl}_{2}(1.7 \mathrm{mM}), \mathrm{MgCl}_{2}$ $(2 \mathrm{mM})$, actomyosin $(0.3 \mathrm{mg} / \mathrm{ml})$ and $1 \mathrm{mM}$ ATP. The ATP was added as a substrate to initiate the reaction. The reaction was terminated after $1 \mathrm{~min}$ by the addition of $15 \%$ TCA. The amount of inorganic phosphate released was determined by the method of Taussky and Shorr (1953) and expressed in micromoles per milligram of protein per minute ( $\mu \mathrm{M} \mathrm{Pi} / \mathrm{mg}$ protein / $\mathrm{min}$ ).

\section{Statistical analysis}

Data have been expressed as mean \pm S.E.M. The statistical significance was determined by the application of Student's t-test to learn the mean differences between the groups. The differences were assumed significant at $\mathrm{P}<0.05$.

\section{Results}

Effect of clenbuterol on body mass and cardiac muscle growth

Clenbuterol (CB) treatment resulted in significant increase in body weight of the animals after 30 days, as compared to that of control group. Initial body weight of animals in the two groups was $25.66 \pm$ $0.66 \mathrm{~g}$ (control) and $25.76 \pm 0.74 \mathrm{~g}$ (CB group). $\mathrm{CB}$ treatment for 30 days resulted in significantly increased body weights ( $29.33 \pm 0.79 \mathrm{~g}$ ), as compare to $26.10 \pm 0.58 \mathrm{~g}$ of the control group. This accounted for $12.3 \%(n=15$, $\mathrm{p}<0.05)$ increase in the body weight of the animals due to $\mathrm{CB}$ treatment. Heart weight/body weight ratio was also

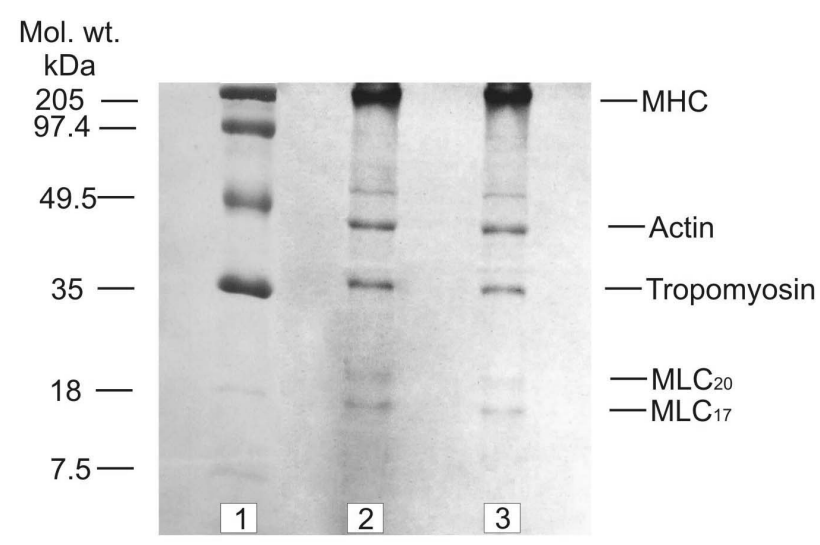

Fig. 2. $12.5 \%$ SDS-PAGE to resolve different myofibrillar proteins. No qualitative differences are visible. Image analysis of the gels showed only insignificant quantitative differences between the different myofibrillar proteins $(n=5)$. Lane 1 molecular weight marker, Lane 2 - Control, Lane 3 Clenbuterol-treated for 30 days, MLC $=$ Myosin Light Chain, MHC $=$ Myosin Heavy Chain

significantly increased by clenbuterol treatment indicating the development of cardiac hypertrophy $(+13.33 \%, n=15, \mathrm{p}<0.05$, Fig. 1$)$.

\section{Myofibrillar proteins (SDS-PAGE)}

Analysis of major myofibrillar proteins employing $12.5 \%$ SDS-PAGE resolved all major myofibrillar proteins (Fig. 2), i.e. MHC (205kDa), actin $(45 \mathrm{kDa})$, tropomyosin $(39 \mathrm{kDa})$ and myosin light chains $(20 \mathrm{kDa}, 17 \mathrm{kDa})$. The different proteins were identified by employing standard molecular weight markers (Sigma Chemicals Co.). Clenbuterol treatment did not result in any qualitative changes between the control and CBtreated groups. In addition, the image analysis of the gels did not reveal statistically significant changes (data not shown) among different proteins between the control and clenbuterol treated groups. Data were normalized for densitometry by loading equal amount of proteins in each lane.

\section{Native PPi-PAGE}

Extraction of native myosin in Guba-Straub extraction buffer and its subsequent analysis on $4 \%$ PPiPAGE showed single band of myosin separated to homogeneity (Fig. 3, n=5) in both control and CB-treated groups. However, when native myosin was equilibrated in Laemmli's buffer and processed for MHC isoform expression, it get resolved into two isoforms of MHC, consistent with our results in separate experiments for MHC isoform expression. 


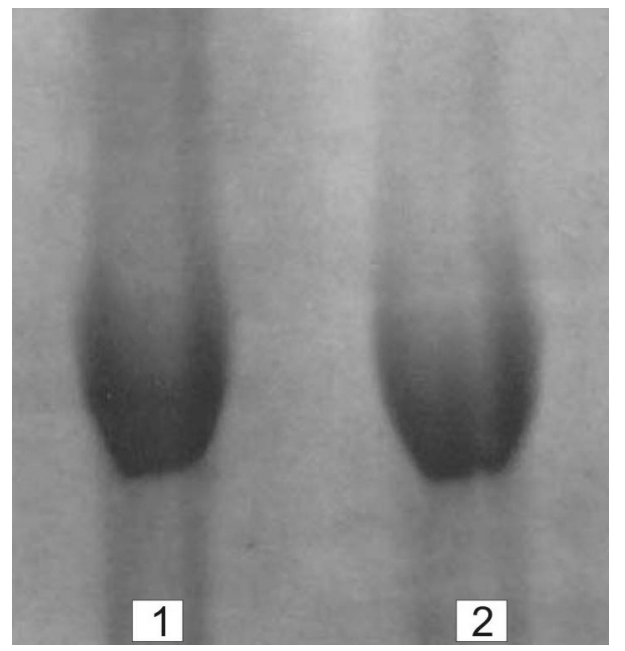

Fig. 3. $4 \%$ PPi-PAGE to resolve native myosin. In both the groups native myosin was separated to homogeneity $(n=5)$. Lane (1) - Control, Lane (2) - CB-treated (treatment period 30 days).

\section{Analysis of MHC isoforms}

Changes in MHC isoform levels from control and CB-treated groups, as analyzed using SDS-PAGE, are presented in Figures $4 \mathrm{a}, 4 \mathrm{~b}$ and $4 \mathrm{c}$. Left ventricular tissue from control group showed almost one isoform of MHC i.e. $\alpha$-MHC (98.16 $\pm 0.14 \%$ ) (Fig. $4 \mathrm{a}$, lane 1, and Fig. $4 \mathrm{~b}$, lane $1 ; \mathrm{n}=5$ ). The other isoform of MHC (i.e. $\beta$-isoform) was present in negligible amounts $(1.83 \pm 0.14$ \%) (Fig. 4a, lane 1, Fig. 4b, lane 1; n=5). However, clenbuterol treatment resulted in significant increase in the levels of $\beta$-MHC (Fig. 4a, lane 2, Fig. 4b, lane 2; $\mathrm{n}=5$ ). In the clenbuterol-treated group, the two isoforms were present in the ratio of $88.05 \pm 1.15 \%$ (Fig. $4 \mathrm{c}, \mathrm{n}=5$ ) $\alpha$-MHC and $11.95 \pm 1.15 \%$ (Fig. $4 \mathrm{c}, \mathrm{n}=5$ ) $\beta$-MHC. A significant decline in the levels of $\alpha$-isoform and corresponding apparent increase in the $\beta$-isoform was recorded due to $\mathrm{CB}$ treatment. Image analysis confirmed a 6.5 fold increase (Fig 4c) in the levels of $\beta$-isoform of myosin heavy chain in the CB-treated group. Several experiments were carried out to confirm the levels of $\beta$-MHC. In the two types of experiments (analysis of MHC from myosin extracted in Guba-Straub extraction buffer, and analysis of MHC from purified myofibrillar pellet extracted by the method of Tsika and colleagues) discussed in the Materials and Methods section, we observed same results. These results suggest that clenbuterol treatment resulted in distinct and significant quantitative changes between the two isoforms accompanied by the altered physiological state of the tissue.
Fig. $4 a$

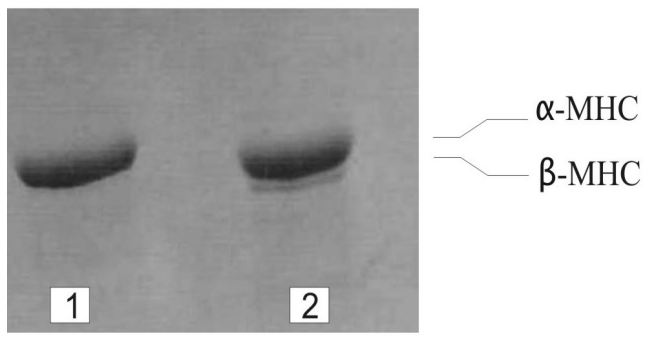

Fig. $4 b$

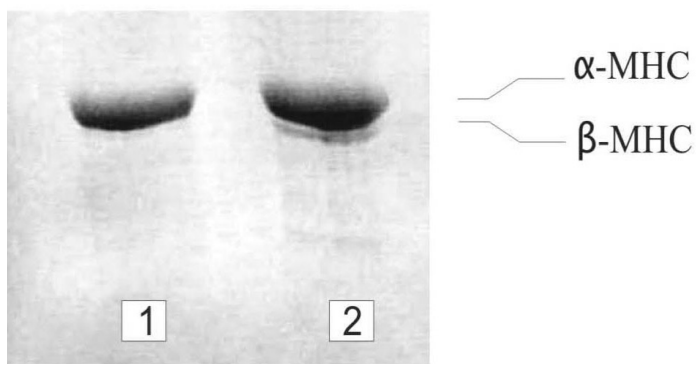

Fig. 4c

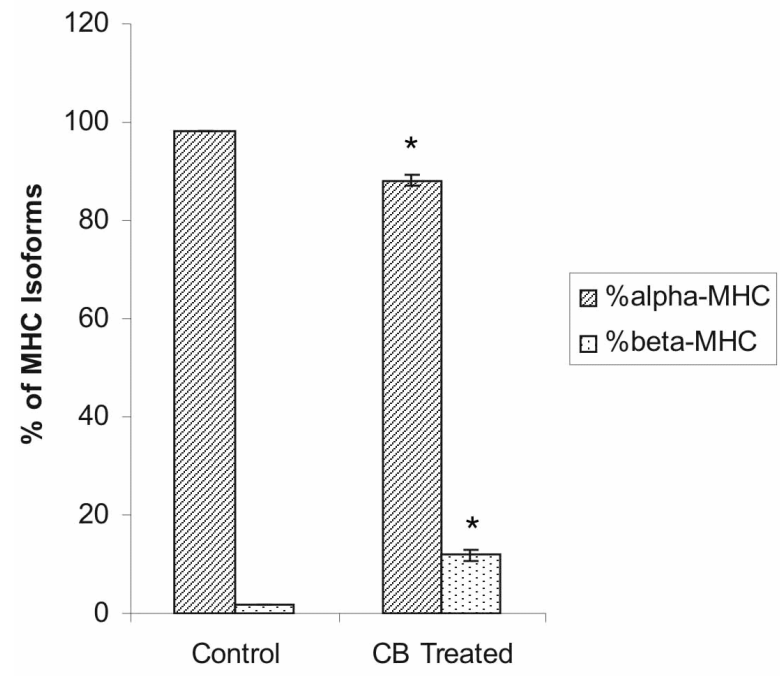

Fig. 4 a. $7.5 \%$ glycerol SDS-PAGE to resolve MHC-isoforms. A significant increase in the expression of $\beta$-MHC was observed $(n=5)$. Myosin used for analysis was extracted in Guba-Straub extraction buffer. Lane (1) - Control , Lane (2) - CB-treated (treatment period 30 days). b. $7.5 \%$ glycerol SDS-PAGE to resolve MHC-isoforms. Purified myofibrillar pellet (extracted by the method of Tsika and colleagues) was analyzed to confirm MHC isoform levels. The experiment confirmed the results, as shown in fig. 4a. Significant increase in $\beta-M H C$ was observed in CB treated group. $(n=5)$, Lane 1 - Control, Lane $2-C B$-treated. C. Relative content (\%) of a- and $\beta-\mathrm{MHC}$ isoform in control and CB-treated groups. * CB treatment significantly $(P<0.05, n=5)$ affected the ratio of the two isoforms. Values are mean \pm S.E.M.

\section{ATPase activity assay}

MHC isoform composition has been postulated to be a key determinant of shortening velocity in the cardiac muscle. The major functional difference between 

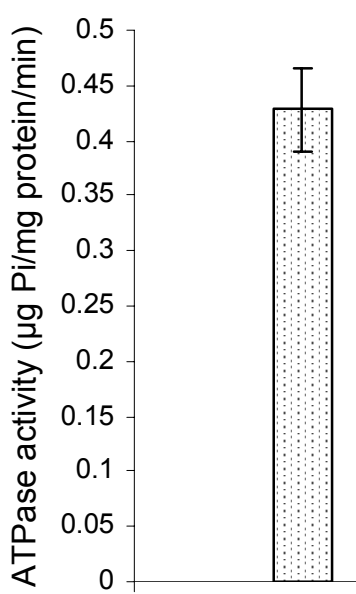

Control

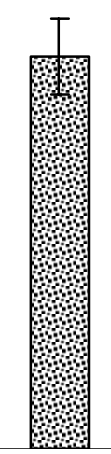

CB Treated

Fig. 5. Actomyosin ATPase activity. * significant decrease in ATPase activity in the CB-treated group. $(P<0.05, n=5)$. Values are mean \pm S.E.M.

the two isoforms is chiefly determined by the intrinsic ATPase activity of the fast $\alpha$ and slow $\beta$-MHC. Actomyosin-ATPase activity assay demonstrated a significant decrease in the ATPase activity of the actomyosin complex in the CB-treated group. ATPase activity from control group had a higher value $0.428 \pm 0.037 \mu \mathrm{M} \mathrm{Pi} / \mathrm{mg}$ protein $/ \mathrm{min}(\mathrm{n}=5)$ as compared to $0.356 \pm 0.034 \mu \mathrm{M} \mathrm{Pi} / \mathrm{mg}$ protein $/ \mathrm{min}(\mathrm{n}=5)$ from the CBtreated group. This indicates an overall decline of $20 \%$ $(\mathrm{p}<0.05, \mathrm{n}=5)$ of the ATPase activity in the tissue after 30 days of clenbuterol treatment (Fig. 5).

\section{Discussion}

The present investigation deals with the chronic effects of $\beta$-adrenoceptor agonist clenbuterol on the left ventricular muscle $\mathrm{MHC}$-isoforms and related changes in ATPase activity of the tissue. Cardiac myosin is a central participant in the cross-bridge cycling that mediates myocyte contraction and consists of multiple subunits that mediate both hydrolysis of ATP and mechanical production of contractile force. Two isoforms of myosin heavy chain (MHC- $\alpha$ and MHC- $\beta$ ) are known to exist in the mammalian cardiac tissue and it is within the myosin subunit that ATPase activity resides (McNally et al. 1989, Schiaffino and Reggiani 1996). The differential expression of the two isoforms changes during various pathophysiological states, hence these serve as important molecular markers during such states.

We have demonstrated that chronic clenbuterol treatment resulted in the establishment of cardiac

hypertrophy, which was found to be associated with a changed composition of MHC isoforms in the left ventricle. An adult mouse heart ventricle normally expresses only the faster $\alpha-\mathrm{MHC}$ isoform (Tardiff et al. 2000). However, in the present study we have observed the expression of both MHC isoforms in control ( $\beta$-MHC $1.83 \pm 0.14 \% ; \mathrm{n}=5$, Fig. $4 \mathrm{c}$ ) and experimental group ( $\beta$-MHC $11.95 \pm 1.15 \% ; n=5$, Fig. $4 \mathrm{c}$ ). The relative expression of these two isoforms in ventricular myocytes is closely related to the resting heart rate and the changes in $\mathrm{MHC}-\alpha / \mathrm{MHC}-\beta$ ratio can be indicative of myocyte adaptive changes. Changes in the levels of MHC isoforms are furthermore related to the ATPase activity of the tissue. We found a significant decline $(20 \%)$ in the ATPase activity in the CB-treated group (Fig. 5). ATPase activity reflects the contractile velocity of a given muscle (Lauer et al.1989). Decrease in the ATPase activity thus correlates well with the increase of $\beta$-MHC-isoform in CB-treated mice.

An increase in the $\beta$-MHC levels and corresponding decrease in the actomyosin ATPase activity in the CB-treated group resulted in cardiac hypertrophy, which is an important fact in the context of contractile performance of the heart. Myosin consisting of $\alpha$-MHC has a higher ATPase activity than myosin composed of $\beta$-MHC (Pope et al. 1980, Vanburen et al. 1995). Quantitatively similar changes in the MHC isoform expression (12\% $\beta$-MHC increase) and ATPase activity (23\% decrease) during genetic alteration of $\mathrm{MHC}$ in the $\alpha \beta$ transgenic mice were shown to reduce the systolic function by $15 \%$ (Tardiff et al. 2000). Small shifts in MHC composition of the myocardium could thus result in physiologically significant changes of the cardiac contractility. In agreement with the earlier reports (Tardiff et al. 2000) the present investigation supports the suggestion that appearance of slow isoform of MHC can be related to a pathophysiological state of the cardiac muscle. Furthermore, various inevestigators (Duncan et al. 2000, Burniston et al. 2002, Patiyal and Katoch 2006) have already reported cardiac cell degeneration and myonecrosis after clenbuterol treatment. Duncan et al. (2000) have concluded that chronic clenbuterol treatment deleteriously affects exercise performance in rats potentially due to alterations in cardiac muscle structure and function.

Myosin is the major protein of the contractile apparatus affecting cross-bridge cycling and hence cardiac contractility. $\beta$-MHC can generate cross-bridge force with a higher economy of energy consumption than 
$\alpha$-MHC. This suggest that shift from $\alpha$-MHC to $\beta$-MHC might be an adaptive response to save energy. Our earlier studies (Patiyal and Katoch 2005, 2006) have confirmed that clenbuterol treatment is capable of causing myonecrosis at chronic low doses and acute high doses that results ultimately in a pathophysiological state of reparative fibrosis. We believe that expression of the $\beta$ MHC may have increased in response to such pathophysiological state, because energy saving changes are required by the tissue in such a state and $\beta$-MHC does so by producing force with less consumption of energy (Holubarsch et al. 1985, Harris et al. 1994). However, this can simultaneously result in the depressed contractile function of the heart and can promote progression of the disease (Tardiff et al. 2000). It is also conceivable that the decrease in the effectivity of contractile function due to an increased $\beta$-MHC might outweigh the benefits of the improved economy.

In combination with our earlier report (Patiyal and Katoch 2006), the present results suggest that chronic clenbuterol treatment affects not only the extracellular components (collagen) of the cardiac muscle, but the changes are also localized in the intracellular components (myosin), as well. Changes in the extracellular component collagen are related with the compliance of the tissue, while changes in the intracellular component myosin contribute to the cross-bridge cycling. Hence, the study has explored the possibility for further investigations on the physiological functions and energetics of the heart after chronic clenbuterol treatment. In summary, chronic clenbuterol treatment results in the remodeling of MHC-isoform composition in the left ventricle of adult mouse heart, which may affect the contractile mechanics of the heart.

\section{Acknowledgements}

Thanks are due to the Council of Scientific and Industrial Research (CSIR) New Delhi for providing financial assistance to SNP. Authors are also thankful to Chairman of Department of Biotechnology Himachal Pradesh University Shimla for providing gel scanning facilities and to Er. J.S. Sodhi for the technical assistance.

\section{References}

AGRAWAL S, THAKUR P, KATOCH SS: $\beta$-adrenoceptor agonists clenbuterol and isoproterenol retard denervation atrophy in rat gastrocnemius muscle. Use of 3-methylhistidine as a marker of myofibrillar degeneration. Jpn J Physiol 53: 229-237, 2003.

BOYD D, 'O' KEEFE M, SMITH MR: Matrix solid phase dispersion as a multiresidue extraction technique for $\beta$ agonist in the bovine liver tissue. Analyst 19: 1467-1470, 1994.

BURNISTON JG, YEELAN NG, CLARK WA, COLYER J, TAN LB, GOLDSPINK DF: Myotoxic effects of clenbuterol in rat heart and soleus muscle. J Appl Physiol 93: 1824-1832, 2002.

BURNISTON JG, TAN LB, GOLDSPINK DF: $\beta_{2}$ adrenergic receptor stimulation in vivo induces apoptosis in rat heart and soleus muscle. J Appl Physiol 98: 1379-1386, 2005.

CHOO JJ, HORAN MA, LITTLE RA, ROTHWELL NJ: Anabolic effects of clenbuterol on skeletal muscle are mediated by $\beta_{2}$-adrenoceptor activation. Am J Physiol 263: E50-E56, 1992.

DELBEKE FT, DESMET N, DEBAKERE M: The abuse of doping agents in competing body builders in Flanders. Int $J$ Sports Med 16: 66-70, 1995.

DUNCAN ND, WILLIAMS DA, LYNCH GS: Deleterious effects of chronic clenbuterol treatment on endurance and sprint exercise performance in rats. Clin Sci 98: 339-347, 2000.

HARRIS DE, WORK SS, WRIGHT RK, ALPERT NR, WARSHAW DM: Smooth, cardiac and skeletal muscle myosin force and motor generation is assessed by cross-bridge mechanical interactions in vitro. $J$ Muscle Res Cell Motil 15: 11-19, 1994.

HOH JFY MCGRATH PA, WHITE RL: Electrophoretic analysis of multiple forms of myosin in fast twitch and slow twitch muscle of chick. Biochem J 157: 87-95, 1976.

HOLUBARSCH RP, GOULETTE RZ, LITTEN BJ, MULIERI LA, ALPERT NR: The economy of isometric force development, myosin isozyme pattern and myofibrillar ATPase activity in normal and hypertrophied rat myocardium. Circ Res 56: 78-86, 1985. 
HON JK, YACOUB MH: Bridge to recovery with the use of left ventricular assist device and clenbuterol. Ann Thorac Surg 75: 536-541, 2003.

INGALL SCP, BARNES WS, SMITH SB: Interaction between clenbuterol and run training: effects on exercise performance and MLC isoform content. J Appl Physiol 80: 795-801, 1996.

KIM YS, SAINZ RD: $\beta$-Adrenergic agonists and hypertrophy of skeletal muscles. Life Sci 50: 397-407, 1992.

KUMAR R, MALHOTRA RK, KATOCH SS: Changes in myosin heavy chain (MHC) expression during pregnancy in rat uterus. Jpn J Physiol 47: 349-354, 1997.

KUMAR S, SHARMA S, KATOCH SS: Early onset of maximum protein anabolic effect induced by isoproterenol in chick skeletal and cardiac muscle. Acta Physiol Hung 90: 57-67, 2003.

LAEMMLI UK: Cleavage of structural proteins during the assembly of the head of bacteriophage $\mathrm{T}_{4}$. Nature 227: 680$685,1970$.

LAUER B, VAN THIEM N, SWYNGHEDAUW B: ATPase activity of the cross-linked complex between cardiac myosin subfragment 1 and actin in several models of chronic overloading. A new approach to the biochemistry of contractility. Circ Res 64: 1106-1115, 1989.

LITTEN RZ, MARTIN RJ, LOW RB, ALPERT R: Altered myosin isozymes patterns from pressure-overloaded and thyrotoxic hypertrophied rabbit hearts. Circ Res 50: 856-864, 1982.

LOWRY ON, ROSEBROUGH MJ, FARR AL, RANDALL RJ: Protein measurement with folin-phenol reagent. $J$ Biol Chem 193: 265-275, 1951.

MCNALLY E, KRAFT R, BRAVO- ZEHNDER M, TAYLOR D, LEINWAND L: Molecular diversity of myofibrillar proteins: gene regulation and functional significance. J Mol Biol 210: 665-671, 1989.

NADAL-GONARD B, MADHVI V: Molecular basis of cardiac performance: plasticity of the myocardium generated through protein isoform switches. J Clin Invest 100: 2362-2370, 1997.

PALMITTER KA, TYSKA MJ, DUPUIS DE, ALPERT NR, WARSHAW DM: Kinetic differences determined at the single molecule level account for functional diversity of the cardiac $\mathrm{V}_{1}$ and $\mathrm{V}_{3}$ myosin isoforms. $J$ Physiol Lond 519: 669-678, 1999.

PATIYAL SN, KATOCH SS: $\beta$-adrenoceptor agonist clenbuterol down regulates matrix metalloproteinase (MMP-9) and results in an impairment of collagen turn over in mice left ventricle. Jpn J Physiol 55: 165-172, 2005.

PATIYAL SN, KATOCH SS: Tissue specific and variable collagen proliferation in Swiss albino mice treated with clenbuterol. Physiol Res 55: 97-103, 2006.

PETROU M, CLARK S, MORRISON K, BOWLES C, DUNN M, YACOUB M: Clenbuterol increases stroke power and contractile speed of skeletal muscle for cardiac assist. Circulation 99: 713-720, 1999.

PIAO S, YU F, MIHM MJ, RESER PJ, MCCARTHY PM, WAGONER DRV, BAUER JA: A Simplified method for identification of human cardiac myosin heavy chain isoforms. Biotechnol Appl Biochem 37: 27-30, 2003.

POPE B, HOH JFY, WEEDS A: The ATPase activities of rat cardiac myosin isozymes. FEBS Lett 118: 205-208, 1980.

ROTHWELL NJ, STOCK MJ: Modification of body composition by clenbuterol in normal and dystrophic (mdx) mice. Biosci Rep 5: 755-760, 1985.

SCHIAFFINO S, REGGIANI C: Full length cDNAs for rat alpha and beta cardiac myosin heavy chain: sequence comparisons suggest a molecular basis for functional differences. Physiol Rev 76: 371-423, 1996.

TARDIFF JC, HEWETT TE, FACTOR M, VIKSTROM KL, ROBBINS J, LEINWAND LA: Expression of the $\beta$ (slow)-isoform of MHC in the adult mouse heart causes dominant- negative functional effects. Am J Physiol 278: H412-H419, 2000.

TAUSSKY HH, SHORR E: A micro colorimetric method for the determination of inorganic phosphorus. $J$ Biol Chem 202: 675-685, 1953.

TSIKA RW, HERRICK RE, BALDWIN KM: Time course of adaptations in rat skeletal muscle isomyosins during compensatory growth and regression. J Appl Physiol 63: 2111-2121, 1987.

VANBUREN P, HARRIS DE, APERT NR, WARSHAW DM: Cardiac $\mathrm{V}_{1}$, and $\mathrm{V}_{3}$ myosins differ in their hydrolytic and mechanical activities in vitro. Circ Res 77: 439-444, 1995. 
ZEMAN RJ., LUDEMANN R, ETLINGER JD: Clenbuterol, a $\beta_{2}$-agonist retards atrophy in denervated muscles. $A m J$ Physiol 252: E152-E155, 1987.

\section{Corresponding author}

Som N. Patiyal, Department of Biosciences, Himachal Pradesh University, Shimla-171005, India. E-mail: snpatiyal@yahoo.co.in 